\title{
Shared Expectations: \\ Identifying Similarities And Differences Be- tween Student And Faculty Teaching Values Based On Student Evaluation Of Faculty Classroom Performance
}

Gregory P. Trudeau, (E-mail: gtrudeau@staff.uwsuper.edu), University of Wisconsin - Superior Kathleen J. Barnes, (E-mail: kbarnes3@staff.uwsuper.edu), University of Wisconsin - Superior

\begin{abstract}
New faculty have an inordinate amount of resources, financial and other, invested in their doctoral degrees. Yet, the first few years can be overwhelming adapting to the plethora of academic life demands. One area of concern that all new faculty deal with is attempting to decode the various stakeholder groups' (i.e., students, colleagues, personnel committee, administration, community and industry members, respective profession colleagues) expectations of the new faculty member and reconciling those with their own personal goals and aspirations. Knowing what each group considers important and highlighting similarities or differences allows new faculty to address stakeholder expectations to better position themselves for a successful and fulfilling career.
\end{abstract}

This paper derives from a study that looked at the two groups (i.e., students and department colleagues) expectations' who most closely affect the daily life of the new faculty member. Study respondents were ask to identify which teaching dimension each group valued most from a list of thirteen questions used by students in evaluating faculty members' classroom performance. Students and faculty members concurred in their clear preference for the instructor knowing the material being presented and the instructor explaining the material in a clear and understandable manner, but differed in their view of the least important teaching dimension depicting a faculty members' classroom performance. The faculty members surveyed concurred with the student ranking that the instructor increasing the student's interest in the subject matter was the second least important teaching dimension depicting a faculty member's classroom performance. This teaching dimension was only superceded by the faculty ranking that the amount of work required being appropriate for the number of credits offered and the student ranking that the instructor stimulating questions was the least important teaching dimension depicting a faculty members', classroom performance.

Background

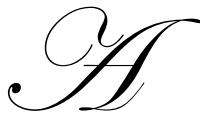

ssessment of faculty performance is truly a complex and multifaceted process. Common components include evaluation of teaching, research, and service (Centra, 1993, p. 1). Depending on the specific mission of the educational institution, research may be emphasized over teaching while at other institutions teaching is emphasized over research. Seldom is service emphasized over research or teaching. Between research and teaching, research is considered the easier and most fairly measured (Braskamp \&

Readers with comments or questions are encouraged to contact the authors via email. 
Ory, 1994, p. 5). The ease of research measurement results from the quantifiable evidence used to evaluate research versus the teaching evaluation evidence. Teaching evaluation often consists largely, if not solely, on student course ratings (Saroyan \& Amundsen, 2001). The quantifiable characteristic of the student course evaluations used as teaching evaluation evidence makes student course evaluations a popular performance evaluation vehicle.

Student course evaluation instruments serve two distinct users for dissimilar uses falling into two primary evaluation categories - formative and summative. The student course evaluations are used for formative evaluation by faculty being evaluated for self-improvement, while summative evaluations are used by peers and administrators to determine retention, promotion, tenure, and salary adjustments.

Ninety-eight percent of 35,000 surveyed faculty believed being a good teacher was one of their essential goals despite only ten percent believing that their educational institutions rewarded good teaching (Centra, 1993, p. 3 ). Faculty needs to be knowledgeable in the needs and wants of the students they teach if faculty are to succeed as good teachers. To obtain this formative guidance, faculty need to know which evaluation characteristics are most and least important to the students who evaluate their performance, so strategies may be adopted and implemented to directly address the student-expressed needs and desires. Over time, this simple process should provide much needed insight for the instructor to gently guide him or her to the necessary or desired teaching technique adjustments allowing continuous instructor teaching methodology improvement while at the same time positively increasing student satisfaction. Clearly these varied teaching evaluation uses show the importance, value, and need faculty have in obtaining a deeper understanding of the student course instruments their educational institutions use to conduct student course evaluations.

A different set of 'uses and users' exists with the summative evaluation where the stakes increase substantially. Peer or personnel committees use summative evaluations in retention, promotion, tenure and salary decisions. One would anticipate that a personnel committee, consisting of tenured faculty, would differ from the students in their value of teaching dimensions on a teaching evaluation instrument. Conscious of the summative evaluations' use, reviewed faculty would do well to determine which questions within the evaluation instrument the personnel committee considers most and least important.

\section{The Setting: The University of Wisconsin-Superior}

The stakes appear to be getting higher as accountability pressures increase despite decreasing financial resources (Braskamp \& Ory, 1994, p xiii). The University of Wisconsin system mandates the use of student course evaluations in the summative evaluation process for retention, promotion, tenure, and salary decisions, while optional self-improvement (formative evaluation) is another facet of student course evaluation. Given the dichotomous use of the same student rating instrument, casts the importance of these evaluations in a totally different light such that the faculty member needs to know as much about these two evaluation facets as possible.

At the University of Wisconsin - Superior (UW-Superior) Department of Business and Economics, teaching makes up $65-75 \%$ of the weighted evaluation process (See Exhibit A: Article II: Department Retention, Promotion, Salary Adjustment, Tenure, and Post-Tenure Criteria). Of this 65 - 75\% teaching amount, student course evaluations constitute the major evidence source. At the end of each semester, students evaluate faculty members' classroom performance with the Student Evaluation of Instruction course evaluation instrument (See Exhibit B for the student course evaluation used within the Department of Business and Economics at the University of Wisconsin-Superior).

\section{The Study}

The UW - Superior Department of Business and Economics student and faculty population were surveyed for this study. 376 students enrolled in business-related courses offered by the Department of Business and Economics and 15 faculty members responded to questions for this study in February 2002. 
Each class offered during the Spring 2002 semester received a package including an instruction sheet (See Exhibit C), the necessary number of Student Teaching Dimension Surveys printed on blue paper stock (See Exhibit D), and one Faculty Teaching Dimension Survey printed on ivory paper stock (See Exhibit E). Questionnaires were distributed to the 49 scheduled classes on the same day to be completed within the next five class days to achieve consistent participation of all students and faculty within the department.

The Student and Faculty Teaching Dimension Surveys (Exhibits D and E, respectively) listed verbatim the first thirteen closed-ended questions from the Student Evaluation of Instruction (see Exhibit B) students use to evaluate instructors' performance. Students and faculty rated each of the thirteen questions regarding its importance in depicting a faculty member's classroom performance using a Likert-type rating scale with $1=$ least important and 5 $=$ most important. Two opened-ended questions not on the original Student Evaluation of Instruction instrument were asked of both the students and the faculty members. The first and second questions asked which of the thirteen questions were considered the most and least indicative, respectively of an instructor's teaching performance and why. Finally, the respondents were asked which year (i.e., freshman, sophomore, junior, senior) best described the students' college standing while the faculty members were asked which category (i.e., tenured, non-tenured) best described the faculty members' status.

\section{Results and Discussion}

\section{Students’ Perception of Most Important Teaching Dimensions}

The students surveyed felt that the instructor explaining the material in a clear and understandable manner was the most important teaching dimension depicting a faculty member's classroom performance followed closely by the instructor knowing the material that is being presented (see Table 1). Increasing learning and improving teaching were seen as the major benefits of instructors performing well on these two teaching dimensions. One student stated, "if the material is clearly explained, students have a good chance of understanding the material which is the primary focus of education." while another student continued on with, "The instructor knowing the material is critical to our gaining the knowledge of the subject." Another student suggested, "Instructor should be able to explain things without having to look in a book and enjoy teaching the class because it is what they excel at." while another student declared that, "If they [instructors] can't get the material across I might as well read some foreign language - I am just not going to get it."

Table 1:

Teaching Dimensions by Student Status

\begin{tabular}{|c|c|c|c|c|c|}
\hline \multirow[b]{2}{*}{ Teaching Dimension } & \multicolumn{3}{|c|}{ Student Status } & & \multirow{2}{*}{$\begin{array}{l}\text { Overall } \\
\text { Student } \\
\text { Ranking }\end{array}$} \\
\hline & Freshman & Sophomore & Junior & Senior & \\
\hline Knows Material & $14.6 \%$ & $19.2 \%$ & $26.8 \%$ & $39.5 \%$ & 2 \\
\hline Clear Explanation & $14.4 \%$ & $22.2 \%$ & $25.0 \%$ & $38.4 \%$ & 1 \\
\hline Stimulating Classroom & $14.5 \%$ & $21.7 \%$ & $24.6 \%$ & $39.1 \%$ & 8 \\
\hline Well-Organized Class & $15.2 \%$ & $22.1 \%$ & $23.4 \%$ & $39.3 \%$ & 6 \\
\hline Instructor Enjoys Teaching & $17.1 \%$ & $28.1 \%$ & $24.0 \%$ & $30.8 \%$ & 9 \\
\hline Approachable Instructor & $18.9 \%$ & $22.2 \%$ & $23.6 \%$ & $35.4 \%$ & 4 \\
\hline Appropriate Amount of Work & $14.9 \%$ & $22.4 \%$ & $23.9 \%$ & $38.8 \%$ & 10 \\
\hline Fair Grading System & $17.4 \%$ & $22.9 \%$ & $25.4 \%$ & $34.3 \%$ & 5 \\
\hline Relevant Exams/Evaluations & $15.4 \%$ & $22.4 \%$ & $26.3 \%$ & $36.0 \%$ & 3 \\
\hline Instructor Increases Interest in Subject & $20.2 \%$ & $23.2 \%$ & $24.2 \%$ & $32.3 \%$ & 12 \\
\hline Instructor Availability & $20.0 \%$ & $17.9 \%$ & $24.8 \%$ & $37.2 \%$ & 7 \\
\hline Instructor Stimulates Questions & $18.0 \%$ & $18.0 \%$ & $23.0 \%$ & $41.0 \%$ & 13 \\
\hline Instructor Challenges Student To Do Best & $17.6 \%$ & $21.2 \%$ & $23.5 \%$ & $37.6 \%$ & 11 \\
\hline
\end{tabular}

Bold = Highest Dimension

Bold Italic $=$ Lowest Dimension 
Freshman students felt that the instructor increasing their interest in the subject matter $(20.2 \%)$ and the instructor available for help outside of class $(20.0 \%)$ were the most important dimensions depicting a faculty member's classroom performance while sophomore students felt that the instructor enjoying teaching their class (28.1\%) was the most important dimension depicting a faculty member's classroom performance. Junior students felt that the instructor knowing the material being presented (26.8\%) and exams/evaluation instruments are relevant to the material covered $(26.3 \%)$ were the most important dimensions representing the classroom performance of a faculty member while senior-level students felt the instructor stimulating questions (41.0\%) and knowing the material being presented (39.5\%) were the most important indicators of a faculty member's classroom performance. Interestingly, when the students were asked directly which of the thirteen questions they considered the most indicative of an instructor's teaching performance, the instructor knowing the material being presented was felt across all the student status categories (freshman to senior) to be the most indicative of an instructor's classroom performance with 30.5 $53.6 \%$ of the responses (see Table 2).

Table 2:

Most and Least Indicative Teaching Dimension by Student and Faculty Status

\begin{tabular}{|c|c|c|c|c|c|c|}
\hline & \multicolumn{2}{|c|}{ Student Status } & \multicolumn{4}{|c|}{ Faculty Status } \\
\hline & Freshman & Sophomore & Junior & Senior & Tenured & Non-Tenured \\
\hline \multicolumn{7}{|l|}{ Most Indicative Teaching Dimension } \\
\hline Knows Material & $30.5 \%$ & $45.3 \%$ & $53.6 \%$ & $47.4 \%$ & & $45.5 \%$ \\
\hline Clear Explanation & & & & & $50.0 \%$ & \\
\hline Instructor Challenges Student To Do Best & & & & & $50.0 \%$ & \\
\hline \multicolumn{7}{|l|}{ Least Indicative Teaching Dimension } \\
\hline Appropriate Amount of Work & $21.8 \%$ & & & & $75.0 \%$ & \\
\hline Instructor Increases Interest in Subject & & $25.0 \%$ & & $24.1 \%$ & & $63.6 \%$ \\
\hline Instructor Stimulates Questions & & & $25.6 \%$ & & & \\
\hline
\end{tabular}

\section{Students' Perception of Least Important Teaching Dimension}

If the course is well-taught there should be no questions, questions should generate themselves, and it's the student's job to ask questions were proposed as explanation why the instructor stimulating questions was viewed as the least important teaching dimension depicting a faculty member's classroom performance (see Table 1). One student declared, "I don't think this [questions] is necessary to show if a teacher is doing a good job because if they did a good job there wouldn't be questions." while other students added, "While the course material is engaging and presented in a clear manner - questions will automatically arise without instructor initiation." and "If students have questions that shouldn't need prompting to ask them." Additionally, teaching is the main emphasis, taking required or general education courses, and students learn differently were projected as accounting for why the instructor increasing the student's interest in the subject matter was perceived as the second least important teaching dimension depicting a faculty member's classroom performance (see Table 1). One student offered, "The instructor is there to teach - every student has different interests. If an instructor tries to increase interest he/she may be losing other points. It's irrelevant." followed by, "There are some classes you just need to take to take and you won't always be interested in it." concluding with, "Students have individual preferences, so instructors can't change our minds about what subjects interest us or not."

Freshman students felt that the instructor creating a stimulating classroom environment (14.5\%) and the instructor explaining the material in a clear and understandable manner (14.4\%) were the least important dimensions illustrating a faculty member's classroom performance while sophomore-level students felt that the instructor stimulating questions (18.0\%) and the instructor available for help outside class (17.9\%) were the least important dimensions depicting a faculty member's classroom performance. Junior-level students felt that the instructor stimulating questions $(23.0 \%)$ was the least important dimension representing the classroom performance of a faculty member 
while senior students felt the instructor increasing their interest in the subject matter (32.3\%) and instructor enjoying teaching the class $(30.8 \%)$ were the least important indicators of a faculty member's classroom performance. Intriguingly, when the students were asked directly which of the thirteen questions they considered the least indicative of an instructor's teaching performance, sophomore- $(25.0 \%)$ and senior-level $(24.1 \%)$ students considered the instructor increasing their interest in the subject matter was the least indicative of an instructor's classroom performance (see Table 2). Freshman-level students viewed the amount of work required being appropriate for the number of credits offered (21.8\%) while junior-level students regarded the instructor stimulating questions $(25.6 \%)$ to be the least indicative of an instructor's classroom performance (see Table 2).

\section{Faculty Member Perception of Most Important Teaching Dimensions}

The faculty members surveyed concurred with the student ranking and felt that the instructor explaining the material in a clear and understandable manner was the most important teaching dimension depicting a faculty member's classroom performance followed closely by the instructor knowing the material that is being presented (see Table 3). Tenured faculty members felt that the instructor available for help outside of class $(60.0 \%)$ and the instructor enjoying teaching the class $(50.0 \%)$ were the most important dimensions depicting a faculty member's classroom performance while untenured faculty members believed that the instructor increasing the student's interest in the subject matter $(100.0 \%)$ and the amount of work being appropriate for the number of credits offered $(100.0 \%)$ were the most important dimension depicting a faculty member's classroom performance.

\begin{tabular}{|c|c|c|c|}
\hline \multicolumn{4}{|c|}{$\begin{array}{c}\text { Table 3: } \\
\text { Teaching Dimension by Faculty Status }\end{array}$} \\
\hline \multirow{2}{*}{ Teaching Dimension } & \multicolumn{2}{|c|}{ Faculty Status } & \multirow{2}{*}{$\begin{array}{l}\text { Overall Fa- } \\
\text { culty Rank- } \\
\text { ing }\end{array}$} \\
\hline & Tenured & Non-Tenured & \\
\hline Knows Material & $40.0 \%$ & $60.0 \%$ & 2 \\
\hline Clear Explanation & $36.4 \%$ & $63.6 \%$ & 1 \\
\hline Stimulating Classroom & $25.0 \%$ & $75.0 \%$ & 10 \\
\hline Well-Organized Class & $20.0 \%$ & $80.0 \%$ & 3 \\
\hline Instructor Enjoys Teaching & $50.0 \%$ & $50.0 \%$ & 11 \\
\hline Approachable Instructor & $42.9 \%$ & $57.1 \%$ & 4 \\
\hline Appropriate Amount of Work & $0.0 \%$ & $100.0 \%$ & 13 \\
\hline Fair Grading System & $33.3 \%$ & $66.7 \%$ & 7 \\
\hline Relevant Exams/Evaluations & $28.6 \%$ & $71.4 \%$ & 5 \\
\hline Instructor Increases Interest in Subject & $0.0 \%$ & $100.0 \%$ & 12 \\
\hline Instructor Availability & $60.0 \%$ & $40.0 \%$ & 6 \\
\hline Instructor Stimulates Questions & $33.3 \%$ & $66.7 \%$ & 9 \\
\hline Instructor Challenges Student To Do Best & $33.3 \%$ & $66.7 \%$ & 8 \\
\hline
\end{tabular}

Bold = Highest Dimension

Bold Italic $=$ Lowest Dimension

\section{Faculty Member Perception of Least Important Teaching Dimensions}

The faculty members surveyed essentially concurred with the student ranking that the instructor increasing the student's interest in the subject matter with a second lowest ranking as the least important teaching dimension depicting a faculty member's classroom performance. This teaching dimension was only superceded by the amount of work required being appropriate for the number of credits offered while students felt the instructor stimulating questions was the least important teaching dimension depicting a faculty members' classroom performance (see Table 3). Tenured faculty members felt that the instructor increasing the student's interest in the subject matter $(0.0 \%)$ and the amount of work required being appropriate for the number of credits offered $(0.0 \%)$ were the least important dimensions depicting a faculty member's classroom performance while untenured faculty members believed that the instructor being available for help outside of class (40.0\%) and the instructor enjoying teaching (50.0\%) were the least important dimension depicting a faculty member's classroom performance. 


\section{Study Limitations}

While this study has been carefully planned and executed, there are potential threats to internal and external validity that bear mentioning. Threats to internal validity include: maturation in the way respondents change over time that might affect the results, conceptualization and operationalization of the teaching effectiveness concept, and the reliability of the measures. Threats to external validity affecting the generalizability of this study's findings include: the effects of students or faculty members' previous history with prior teachers and/or teaching; the effects of measuring effective teaching in specific classrooms with specific instructors, and the unique program features of an undergraduate business program in a public, Tier III Carnegie liberal arts educational institution.

\section{Further Study}

McKeachie (1987) stated that despite the numerous studies completed on instructional evaluation, many other possibilities exist for further areas of study. This study has provided some interesting data regarding the formative and summative use of evaluations, however, other questions surfaced during this study requiring further research. Specially, students and faculty members concurred in their clear preference for the instructor knowing the material being presented and the instructor explaining the material in a clear and understandable manner. It would be interesting to determine which specific teaching methodologies an instructor might incorporate into the classroom to best achieve the classroom performance to address these issues.

\section{References}

1. Braskamp, L. \& Ory, J. (1994). Assessing Faculty Work. San Francisco, CA: Jossey-Bass Publishers.

2. Centra, J. (1993). Reflective Faculty Evaluation. San Francisco, CA: Jossey-Bass Publishers.

3. Cohen, P.A. (1981). Student ratings of instruction and student achievement: A meta-analysis of multisection validity studies. Review of Educational Research, 51, 281-309.

4. Costin, F., Greenough, W.T., \& Menges, R.J. (1971). Student ratings of college teaching: Reliability, validity, and usefulness. Review of Educational Research, 41, 511-535.

5. Cranton, P., \& Smith, R.A. (1990). Reconsidering the unit of analysis: A model of student ratings of instruction. Journal Of Educational Psychology, 82, 207-212.

6. Felkman, K. (1978). Course characteristics and college students' ratings of their teachers: What we know and what we don't. Research In Higher Education, 9, 199-242.

7. Howell, A.J. \& Symbaluk, D.G. (2001). Published student ratings of instruction: Revealing and reconciling the views of students and faculty. Journal Of Educational Psychology, 93 (4), 790-796.

8. Marsh, H.W. (1984). Student's evaluations of teaching: Dimensionality, reliability, validity, potential biases, and utility. Journal Of Educational Psychology, 76, 707-754.

9. McKeachie, W.J. (1987). Instructional evaluation: Current issues and possible improvements. Journal Of Higher Education, 58, 344-350.

10. Perry, R.P., Abrami, P.C., \& Leventhal, L. (1979). Educational seduction: The effect of instructor expressiveness and lecture content on student ratings and achievement. Journal Of Educational Psychology, 71, 107-116.

11. Saroyan, A., \& Amundsen, C. (2001). Evaluating university teaching: Time to take stock. Assessment \& Evaluation In Higher Education, 26, (4), 341-353. 


\title{
Exhibit A: Business and Economics Department, University of Wisconsin - Superior
}

\author{
Article II: Department Retention, Promotion, Salary Adjustment, Tenure, And Post-Tenure Criteria
}

The Department Chair will conduct face-to-face reviews with each Department member on a regular basis. Additional interim meetings can be arranged to discuss progress and revise objectives. The Chair will meet at least annually with individual untenured faculty members to discuss their progress toward tenure and also on an annual basis with academic staff. In accordance with UW-System policy, Extension activities will be considered in the evaluation of those Department members who are engaged in Extension work.

Recognizing that efforts and successes in different evaluation categories will vary by individual and time frame, the person being evaluated will identify the weights he or she wishes in each of the following categories, within established ranges. The Personnel Committee will recommend decisions regarding retention, promotion, salary adjustment, tenure, and post-tenure to the appropriate administrator following University policy guidelines.

\section{Mentors}

It is strongly recommended that mentors be assigned to each tenure-track faculty member to guide the new faculty member throughout the probationary period. Effective service as a mentor should be recognized as a key element of the faculty member's Department and University service during the salary and retention reviews.

IA. Teaching: $(60 \%-75 \%)$ Any or all of the following may be considered:
a. Advisement
b. Extent to which you have encouraged the improvements of students' writing and speaking skills in your courses.
c. Curriculum development.
d. Self-evaluation and/or development.
e. Strengths and weaknesses as a teacher.
f. Instructional workload.
g. Student reaction.
h. Other (such as contributions to the Strategic Planning Goals).

IB. Primary Responsibility, Non-Teaching: (60\%-75\&)

For those members whose primary responsibility is other than teaching, criteria will be developed according to the individual's responsibilities.

Areas II through VI will be collectively weighted $25 \%-40 \%$.

\section{Scholarship:}

For evaluation purposes. Department members should provide written documentation of scholarship activities. Scholarship of Department members will be viewed broadly, in accordance with Boyer's ${ }^{1}$ four separate but overlapping functions:

a. Scholarship of Discovery -Work that contributes to the stock of human knowledge and to the intellectual climate of the University, including, but not limited to, papers published in refereed publications or presented at professional meetings.

\footnotetext{
${ }^{1}$ Ernest L. Boyer, Scholarship Reconsidered: Priorities of the Professoriate, 1997.
} 
b. Scholarship of Integration -Work that is interdisciplinary, interpretive, and/or seeks to integrate or synthesize. Making connections across disciplines, placing academic specialties in larger context, illuminating data in a revealing way, and educating non-specialists. Work that seeks to interpret, draw together, and bring new insight to bear on original research.

c. Scholarship of Application -Academic work or service that serves the larger community, that is tied directly to one's special field of knowledge and which relates to, and flows out of, one's professional activity. Investigation that responds to the questions "How can knowledge be responsibly applied to consequential problems of society?" or "How can knowledge be helpful to individuals as well as institutions?"

d. Scholarship of Teaching -Evaluation of a departmental member's teaching performance may include, but need not be limited to the following elements:

1. Staying well informed and steeped in the knowledge of one's field.

2. Demonstrating that pedagogical procedures are carefully planned, continuously examined, and related directly to the subjects taught.

3. Demonstrating successful implementation of the Seven Principles of Good Undergraduate Teaching.

\section{Professional Development:}

Other professional development activities such as attendance at conferences, carrying out grant projects, memberships/offices held in professional associations, and other activities related to your profession.

\section{Community Service:}

a. Professional and Other

1. Invited lectures or presentations to members of community organizations, participation on community boards or advisors

2. Other outreach activities, volunteerism, activities that build ties between town and gown

\section{University and Department Service:}

a. Membership and participation of committees

b. Special projects and ad hoc appointments

c. Service as a mentor of probationary faculty

\section{Miscellaneous:}

a. Honors, awards, etc.

b. Progress toward terminal degree (where appropriate)

The preceding are the specific criteria used to evaluate all Department members. Although each Department member will receive an evaluation in categories I through VI, it is recognized that contributions in these areas will differ, depending on the nature of each member's appointment, and his or her unique strengths and interests.

A post-tenure review will encompass an entire five-year period, and will focus on each faculty member's activities in accordance with his or her plans, interests, and available opportunities.

Approved 3/8/99, Revised 4/18/2001

Exhibit B: Student Evaluation of Instruction (Page 1), University of Wisconsin - Superior 


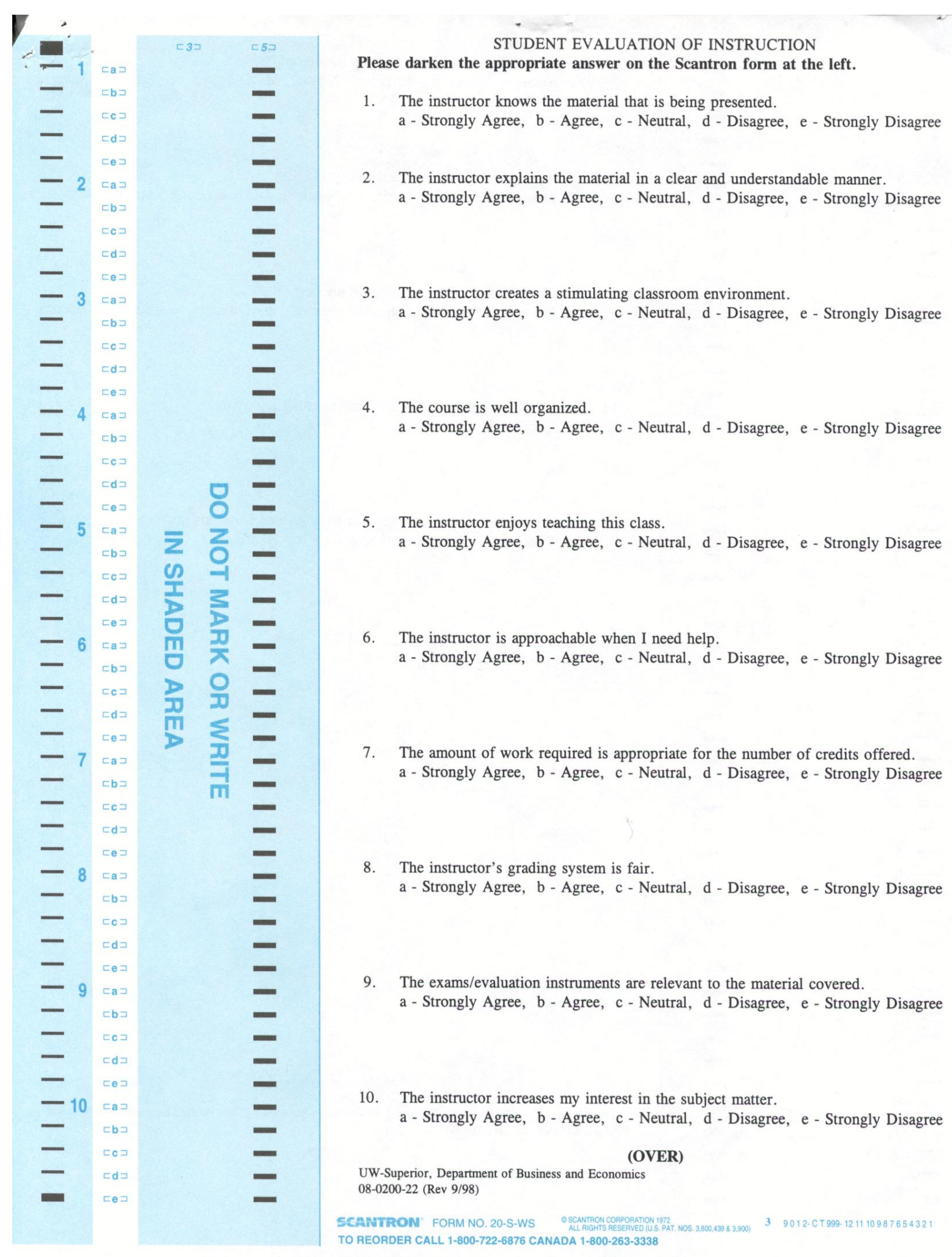

Exhibit B: Student Evaluation of Instruction (Page 2), University of Wisconsin - Superior 


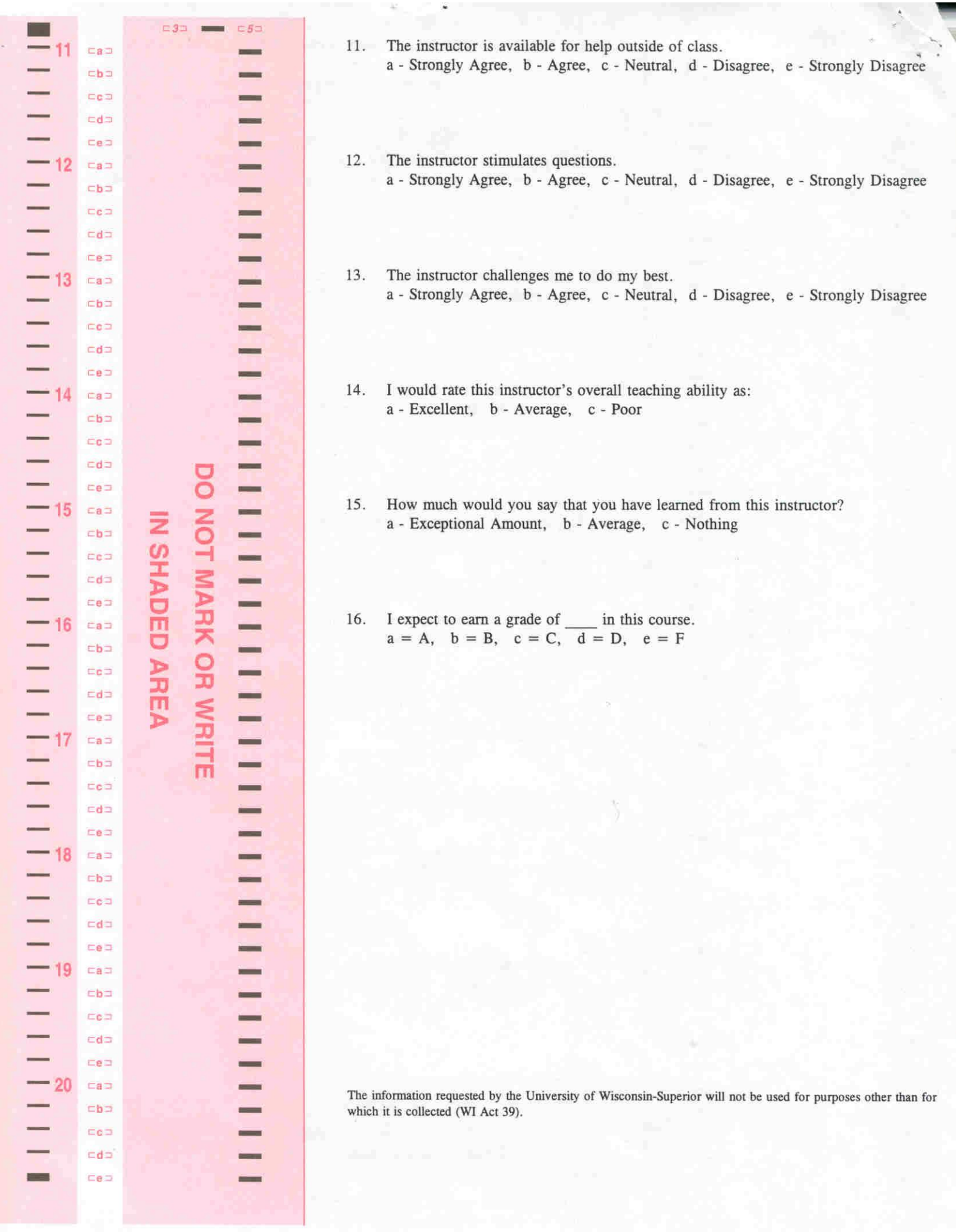

Exhibit B: Student Evaluation of Instruction (Page 3), University of Wisconsin - Superior 
Student Evaluation Of Instruction Page 2

Please answer the following questions. Use the back of this sheet if necessary.

What are your feelings about the book used in this course?

What did you like about this instructor and/or course?

What did you dislike about this instructor and/or course?

Do you have any suggestions on how to improve this course?

\section{Exhibit C: Teaching Dimension Survey Instructions}

Survey Instructions

Please Read To Class

At the end of each semester, the Department of Business and Economics asks the students to complete a questionnaire "Student Evaluation of Instruction" (copy attached which you may show the class for clarification). The questionnaire you are about to receive, asks you to rate the same thirteen questions found on the "Student Evaluation of Instruction" according to which questions you consider least important and those you considered most important.

Please indicate for each question how you would rate its importance.

Also, please indicate in question \#14 and \#15 which question you feel is the most and indicative and least indicative of an instructor's teaching performance.

If you (instructor or student) have already completed the questionnaire in another class, please do not complete another questionnaire.

Please have one student agree to bring the completed instruments up to the office secretary.

Instructors Note: Blue questionnaires are for students to complete, Ivory is for the instructor to complete.

Thank you for your help,

Kathleen Barnes

William Higbee

Shaun Lynch

Gregory Trudeau

Exhibit D: Student Teaching Dimension Survey 


\begin{tabular}{|c|c|c|c|c|c|}
\hline \multirow{3}{*}{$\begin{array}{l}\text { Teaching Dimension Survey } \\
\text { 1. The instructor knows the material that is being presented. }\end{array}$} & \multicolumn{5}{|c|}{ Importance } \\
\hline & \multicolumn{5}{|c|}{$\begin{array}{l}1=\text { Least Importan } \\
5=\text { Most Important }\end{array}$} \\
\hline & 1 & 2 & 3 & 4 & 5 \\
\hline 2. The instructor explains the material in a clear and understandable manner. & 1 & 2 & 3 & 4 & 5 \\
\hline 3. The instructor creates a stimulating classroom environment. & 1 & 2 & 3 & 4 & 5 \\
\hline 4. The course is well organized. & 1 & 2 & 3 & 4 & 5 \\
\hline 5. The instructor enjoys teaching this class. & 1 & 2 & 3 & 4 & 5 \\
\hline 6. The instructor is approachable when I need help. & 1 & 2 & 3 & 4 & 5 \\
\hline 7. The amount of work required is appropriate for the number of credits offered. & 1 & 2 & 3 & 4 & 5 \\
\hline 8. The instructor's grading system is fair. & 1 & 2 & 3 & 4 & 5 \\
\hline 9. The exams/evaluation instruments are relevant to the material covered. & 1 & 2 & 3 & 4 & 5 \\
\hline 10. The instructor increases my interest in the subject matter. & 1 & 2 & 3 & 4 & 5 \\
\hline 11. The instructor is available for help outside of class. & 1 & 2 & 3 & 4 & 5 \\
\hline 12. The instructor stimulates questions. & 1 & 2 & 3 & 4 & 5 \\
\hline 13. The instructor challenges me to do my best. & 1 & 2 & 3 & 4 & 5 \\
\hline
\end{tabular}

14. Which of the above thirteen questions do you consider the most indicative of an instructor's teaching performance? Why?

Question Number

15. Which of the above thirteen questions do you consider the least indicative of an instructor's teaching performance? Why? Question Number

16. Which of the following best describes the year you currently are in college?

Freshman

Sophomore

Junior

Senior

Exhibit E: Faculty Teaching Dimension Survey 
Teaching Dimension Survey

1. The instructor knows the material that is being presented.

2. The instructor explains the material in a clear and understandable manner.

3. The instructor creates a stimulating classroom environment.

4. The course is well organized.

5. The instructor enjoys teaching this class.

6. The instructor is approachable when I need help.

7. The amount of work required is appropriate for the number of credits offered.

8. The instructor's grading system is fair.

9. The exams/evaluation instruments are relevant to the material covered.

10. The instructor increases my interest in the subject matter.

11. The instructor is available for help outside of class.

12. The instructor stimulates questions.

13. The instructor challenges me to do my best.

Importance
$1=$ Least Important
$5=$ Most Important

$\begin{array}{lllll}1 & 2 & 3 & 4 & 5\end{array}$

$\begin{array}{lllll}1 & 2 & 3 & 4 & 5\end{array}$

$\begin{array}{lllll}1 & 2 & 3 & 4 & 5\end{array}$

$\begin{array}{lllll}1 & 2 & 3 & 4 & 5\end{array}$

$\begin{array}{lllll}1 & 2 & 3 & 4 & 5\end{array}$

$\begin{array}{lllll}1 & 2 & 3 & 4 & 5\end{array}$

$\begin{array}{lllll}1 & 2 & 3 & 4 & 5\end{array}$

$\begin{array}{lllll}1 & 2 & 3 & 4 & 5\end{array}$

$\begin{array}{lllll}1 & 2 & 3 & 4 & 5\end{array}$

$\begin{array}{lllll}1 & 2 & 3 & 4 & 5\end{array}$

$\begin{array}{lllll}1 & 2 & 3 & 4 & 5\end{array}$

$\begin{array}{lllll}1 & 2 & 3 & 4 & 5\end{array}$

$\begin{array}{lllll}1 & 2 & 3 & 4 & 5\end{array}$

14. Which of the above thirteen questions do you consider the most indicative of an instructor's teaching performance? Why?

Question Number

15. Which of the above thirteen questions do you consider the least indicative of an instructor's teaching performance? Why? Question Number

16. Which of the following best describes your faculty status?

Tenured Nontenured

Notes

${ }^{2}$ Gregory P. Trudeau, CPA, CMA, CIA, CFE, Ed.D., is a Professor of Accounting at the University of Wisconsin - Superior and can be reached at (715) $394-8209$ or gtrudeau@ @staff.uwsuper.edu.

Kathleen J. Barnes, ABD in Organizational Studies, is an Assistant Professor of Management at the University of Wisconsin - Superior and can be reached at (715) $394-8466$ or kbarnes3@staff.uwsuper.edu.

The mailing address is: University of Wisconsin - Superior, Belknap \& Catlin, P.O. Box 2000, Superior, WI 54880. 